\title{
Intercropping - a Successful System for Runner Bean (Phaseolus coccineus L.) Crop
}

\author{
Silvia Brîndușa HAMBURDA ${ }^{\left.1^{*}\right),}$ Neculai MUNTEANU ${ }^{1)}$ and Gabriel Ciprian TELIBAN ${ }^{1)}$ \\ ${ }^{1}$ Faculty of Horticulture, Department of Horticultural technologies. University of Agricultural Sciences \\ and Veterinary Medicine Iasi, 3, Mihail Sadoveanu Alley, 700490, Iasi, Romania; \\ ${ }^{*}$ Corresponding author, e-mail: silvia_hamburda@yahoo.com
}

Bulletin UASVM Horticulture 72(1) / 2015

Print ISSN 1843-5254, Electronic ISSN 1843-5394

Doi:10.15835/buasvmcn-hort:10453

\begin{abstract}
This paper presents an overview of the specialized literature on the use of intercropping system for runner bean crop (Phaseolus coccineus L.). The aim of this paper is to present the state of knowledge on the use of the interrow or the intercropping system, for increasing the quantity and quality of runner bean production in terms of economic efficiency. The research was made based on comparative studies and case studies, using data from the specialized literature. Intercropping system can be viewed as a managerial practice of increasing the production of certain crops suitable to this system. A situation diversity was highlighted, regarding various combinations and ways of arranging the runner bean with other cultivated species. Their advantages and disadvantages have been analyzed, as well as the possibilities of their application in Romania. As a general conclusion, runner bean is a species that can successfully suit the intercropping system in the ecological conditions of Romania.
\end{abstract}

Keywords: associated crops, crop competition, establishment design, sunflower, The Three Sister Method.

\section{INTRODUCTION}

In Romania, the runner bean (Phaseolus coccineus L.) has been very little studied, both as a species and crop used in method of cultivation. The first significant signal, especially regarding the importance of the culture and the technology of cultivation, was realized by Munteanu (1985). Since 2000, runner bean has been investigated in more detail (Popa, 2010). Being a cool and humid climate vegetable species, in the steppe conditions of Romania, the crop is subject to soil and atmospheric drought. Therefore, to obtain efficient and stable yields, it is necessary to develop a system of cultivation, in which the technology can adjust the unfavourable environmental conditions (Munteanu, 2005). Such a system can be represented by the interposition of runner bean plants with other cultivated plants, respectively the interleaved cultivation systems or "intercropping".

Intercropping is known for thousands of years (Kass, 1978) and it is the system in which, in the same land area and time, two or more crop species are cultivated (Andrews and Kassam, 1976; Anil et al., 1998 , Ofori and Stern, 1987). The purpose of this system is to put the crops in the same place during their entire growing season or at least for a period of time (Mousavi and Eskandari, 2011). The plants involved in intercropping can be seeded or planted at the same time or at different times (Ofori and Stern, 1987). Intercropping is based on the management of plant interaction in order to increase the productivity (Vandermeer 1989, Willey, 1979a,b). Plants may ameliorate, reciprocally, the environmental conditions and they can increase the availability of resources for each other.

Through the cultivation of intercropped vegetable plants with intercropped non-legumes, the transfer of symbiotically fixed nitrogen to the species in association can be achieved and, also, phosphorus (P) can be released from organic compounds through the work of extracellular enzymes (Dakora, 2003; Ștefan et al., 2013a,b). 
This way, soil fertility can be ameliorated. The interleaving of vegetable plants with cereals is practiced mostly in unirrigated regions, especially in the Mediterranean area (Anil et al., 1998).

\section{MATERIALS AND METHODS}

The achievement of our approach relied on a systematic study based on an extensive bibliography from Romania and abroad. The biological material taken into consideration was the runner bean species. As working methods, we used comparative analysis and case study, based on existing information in the specialized literature, given the possibilities of applying this system of cultivation in the environmental circumstances of our country. Advantages and disadvantages of this cultivation system and possible obstacles in its implementation were highlighted. This analysis is considering the economic efficiency of the crop, based on the quantity and quality of the harvest, risk reduction and costs diminishing.

\section{RESULTS AND DISCUSSIONS}

Intercropping can be seen as a practice to increase less stable crop yields, as the runner bean. In comparison with a pure crop, intercropping is influenced by a series of agronomic practices that, in fact, are the secret of success in this system of cultivation: plant density, date of crops establishment, resources availability and spatial arrangement (Mazaheri et al., 2006).

Runner bean is an annual species, although, at its origins, it is a perennial plant, with a growing season of 120-125 days, alogam pollination, hypogeal emergence with a high ecological plasticity and a high tolerance to some pathogens (Stan et al., 2003). Worldwide, this species is cultivated both as a pure crop and interspersed with other species, setting up extremely varied schemes, both in terms of spatial arrangement and plants association (Hamburdă, 2014; Munteanu, 2013; Olaru 1982; Popa, 2010).

Intercropping can be formed by annual plants interspersed with annual plants, annual plants interspersed with perennial plants and perennial plants interspersed with perennial plants (Eskandari et al., 2009).

Regarding the spatial arrangement, there are at least four basic spatial arrangements used in interspersed crops (Ofori and Stern, 1987; Vandermeer, 1989): (a) row-intercropping, is defined as growing two or more crops simultaneously when at least one crop is sown in rows;

(b) strip-intercropping, involves growing two or more crops at a time in different strips, wide enough to allow independent cultivation, but narrow enough to allow interaction between them;

(c) mixed-intercropping, involves growing two or more crops together in no distinct row arrangement;

(d) relay-intercropping, namely a second crop is sown into a standing crop, when the standing crop is at its reproductive stage, but before harvesting.

Kang et al. (1985) added the hedgerow intercropping, or alley cropping, which involves planting rows of annual crops between rows of trees, which are periodically pruned to minimize the effects of shading. Regardless of the spatial arrangement, the plants which are growing together are in competition for light, water and nutrients (Vandermeer, 1989). As a result, they may have positive or negative influence on each other. Intercropping success depends on a good balance between competition and facilitation, respectively advantages and disadvantages (Fig.1).

The advantages of intercropping make this ancient practice to provide interest even today, when the method is used predominantly in small farms with less developed technologies. These main advantages are: reduction of pests damage due to the diversity of crops; reduction of diseases damage; removal or reduction of weeds, through allelopathy or competition; reduction of erosion of sloping lands and protection of soils (e.g. strip- intercropping); increase or maintainance of organic matter content; attraction of a large number of useful insects, especially when plants that are already blooming are included in the crop system; more efficient use of land on the farm; potential increase in total production and farm profitability, compared with the case where crops are grown separately; increasing diversification of crops in a single growing season; improvement of the microclimate of the agricultural ecosystem etc. (Kass, 1978; Vandermeer, 1989). Also, through this system, an economic efficiency is ensured, by the fact that, if one of the crops is compromised, the other crop may provide revenue. This advantage 


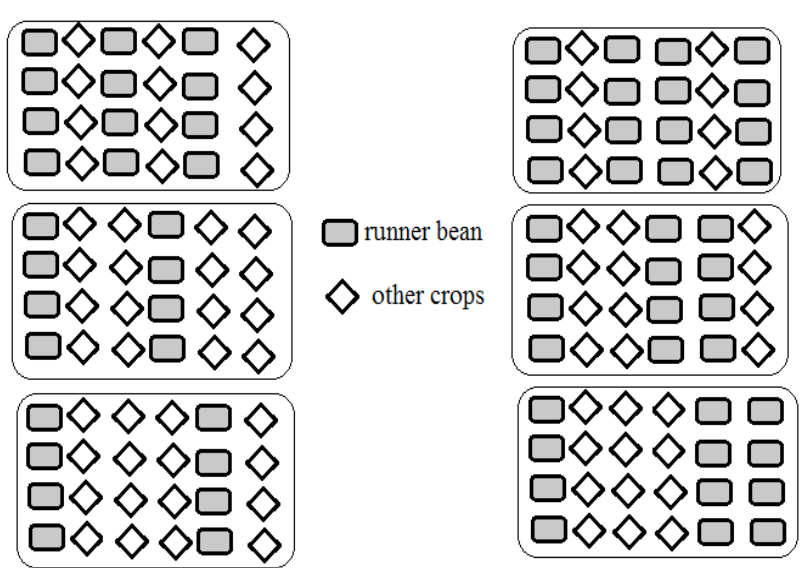

Fig. 1. Row arrangement in intercropping system with runner bean.

is the reason why intercropping system is under development and is more stable compared to monoculture (Eskandari et al., 2009; Horwith, 1985).

Most studies conducted on intercropping system targeted production without putting emphasis on interspecific processes that have contributed to these results. It is well known that light, water, minerals, oxygen and carbon dioxide are the necessary elements for plant growth (Trenbath, 1976). Intercropping success depends on thorough knowledge of the botanical, ecological and technological particularities of the associated species, especially habitus, root morphology, requirements for water and nutrients. Plants compete for light above ground and water and minerals in the soil, so the competition involves a combination of light and soil factors in time and space (Machado, 2009). Haynes (1980) concluded that a proper management of the root system of the associated crops can minimize root competition for water.

The intercropping system disadvantages are: competition for items that are necessary for plant growth and development; impossibility of applying mechanical and/or manual maintenance work and the allelopathic effects that can lead to lower yields etc. (Lithourgidis et al., 2011). Also, the labour requirements of an intercropping system may be higher than sole cropping, as two or more different crops are sown at the same moment or shortly after one another. On the other hand, labour requirements may also be lesser in an intercropping system, for example, due to a reduction of weeding requirements, when weeds are suppressed by the intercrop. If sowing and harvesting periods of different crops vary, it is easier to spread the available labour over the entire season, avoiding its high peaks.

If the competition for nitrogen (N) is taken into account, as a nutrient, it is recommended for vegetable plants to be planted early enough in the growing season to accumulate appreciable amounts of $\mathrm{N}$ from the atmosphere, in order to be effective $\mathrm{N}$ contributors (Eaglesham et al., 1982). Ofori and Stern (1987) showed that intercropping legumes with non-legumes increases the amount of $\mathrm{N}$ fixed by legumes because non-legumes stimulate legumes to maximize their capability to fix N. However, they claimed that legumes have a secondary role in legume-cereal intercroppings. To reduce competition for water and minerals, Andrews and Kassam (1976) recommended to plant crops at different times of the growing season in a relay-intercropping system.

The effect of intercropping on nematode, insect, disease and weed problems is site-specific and difficult to predict and, therefore, must be evaluated for each new intercropping combination separately.

The greatest obstacles in adopting intercropping system are the conceptualization of crop cultivation, the method of fertilization, the method of combating pests and diseases and, in particular, how the harvest is achieved. Considering the vastness of possible intercrop combinations and the countless climatic and soil conditions involved, it is not possible to generalize the recommendations in this regard (Machado, 2009). John Bowen and Bernard Kratky (1986), professors at the University of Hawaii, recommend taking into account five different aspects to achieve a successful intercropping: (1) detailed planning; (2) sowing each crop at optimal time; (3) adequate fertilization at the optimal times; (4) effective control of weeds and pests and (5) efficient harvesting.

Intercropping efficiency can be evaluaed by comparing the productivity of a given area of intercropping with that of sole crops, using the competition functions described below:

$$
\text { Land equivalent ratio, } \quad L E R=\frac{Y_{a b}}{Y_{a a}}+\frac{Y_{b a}}{Y_{b b}}
$$


Where $Y_{a b}$ and $Y_{b a}$ are the individual crop yield in intercropping and $Y_{a a}$ and $Y_{b b}$ are their yields as sole crop (Willey, 1979a).

The LER indicates the relative amount of land required when growing sole crops to achieve the productivity observed in the mixtures. A total LER value $>0.1$ indicates the mixture was more productive than the component sole crops, whereas a value $<0.1$ suggests sole crops were more productive (for example, antagonistic effects). A LER value of 1 indicates no difference in yield between the intercrop and the collection of monocultures.

Land equivalent coefficient

$$
(L E C)=L A \times L B
$$

Where, $L A=L E R$ of main crop and $L B=L E R$ of intercrop (Adetiloye et al., 1983).

For a two crop mixture, the minimum expected product before a yield advantage is obtained is an LEC over 0.25 .

Area time equivalent ratio,

$$
A T E R=\frac{\left(R y_{a} \times t_{a}\right)+\left(R y_{b} \times t_{b}\right)}{T}
$$

Where Ry = Relative yield of species ' $a$ ' or ' $b$ ' for example, yield of intercrop/yield of main crop, $\mathrm{t}=$ duration (days) for species ' $\mathrm{a}$ ' or ' $\mathrm{b}$ ' and $T=$ duration (days) of the intercropping system (Hiebsch and McCollumn, 1987). ATER is only appropiate in systems with component crops of contrasting maturities. When components are of similar growth durations, ATER values are similar to LER. When the difference between growth durations of component crops is substantial, time becomes an important element and ATER is considered to be a more appropiate index of the efficiency of the system (Ofori and Stern, 1987).

$$
\text { Agressivity, } A_{a b}=\left[\frac{Y_{b a}}{Y_{b b} \times Z_{b a}}-\frac{Y_{a b}}{Y_{a a} \times Z_{a b}}\right]
$$

Where $\mathrm{Y}_{\mathrm{ab}}$ and $\mathrm{Y}_{\mathrm{ba}}$ are the individual crop yields in intercropping and $Y_{a a}$ and $Y_{b b}$ are their yields as sole crop. $\mathrm{Z}_{\mathrm{ab}}$ and $\mathrm{Z}_{\mathrm{ba}}$ were proportions of land area occupied on intercropping when compared to sole crop for species ' $a$ ' and ' $b$ ' respectively (Mc Gilchrist, 1965).

Relative crowdind coefficient,

$$
R C C=K_{a b} \times K_{b a}
$$

Where

$$
K_{a b}=\frac{Y_{a b}}{Y_{a a}-Y_{a b}} \text { and } K_{b a}=\frac{Y_{b a}}{Y_{b b}-Y_{b a}}
$$

$\mathrm{K}_{\mathrm{ab}}$ and $\mathrm{K}_{\mathrm{ba}}$ are the RCC for species ' $\mathrm{a}$ 'and ' $\mathrm{b}$ ' respectively (De Wit,1960.)

Intercropping system perfectly folds away in ecological/biological/organical farms and in sustainable crop systems (Vandermeer, 1989). It was a common practice in Europe before mechanisation, plant breeding and use of synthetic fertilizers and pesticides were implemented in a more intensified manner in the agricultural production starting in the 50s. Intercropping perspective in arable systems and the potential area for intercrops in organic farming is large, considering the possible economic benefits and future legal requirements in feed and food industries.

Worldwide (especially in Africa, Sri Lanka, India etc.), but also in our country, runner bean is cultivated interspersed with maize since the beginning of introduction of this plant in culture. This manner of cultivation is advantageous for runner bean crop because maize plants create a favourable microclimate for runner bean plants, which are very susceptible to atmospheric drought, especially in the flowering period. Intercropping is practiced to cover production losses, if one of the crops is compromised (Hamburdă, 2013).

Also, in our country, the cultivation of runner bean associated with maize, but also associated with the Jerusalem artichoke and sunflower is commonly practiced. Their stems are used as a support system for runner bean plants and Jerusalem artichoke and sunflower leaves are removed in order not to obfuscate the runner bean crop, leaving only a few leaves at the top to maintain their vegetation. These cultivation systems are particularly effective, especially in terms of the support system, which is extremely expensive (Hamburdă, 2013). 
Pulses, also called 'legumes', are a protein - rich source of food. The crop residues of the pulse crop are extremely valuable as a silo, both qualitatively and quantitatively, which can be used as fodder by cutting and carrying them to the animals, or by letting the animals graze the residues in the field. The cultivation of runner bean and cereals at the same time allows a mixture harvest and their use directly as forage (legumes compensate protein and cereals provide carbohydrates), or may be harvested separately for individual use (Trenbath, 1976).

„The Three Sisters Method" is a common practice that emphasizes the benefits, considering that maize, climbing beans and squash are three inseparable „sisters”, which only grow and thrive together. This is a long-standing traditional intercrop combination of species in the Americas. One of the names for this combination comes from an Aztec trilogy. Acording to historical records, the farmer dug a hole in the ground and placed one seed of each species into the hole (Scarry, 2008). This method provides increasing soil fertility and maximizes growth space. Thus, the maize provides support system for beans and the beans help to stabilize the maize plants, making them less susceptible to the wind. Pumpkin plants are a living mulch, smother emerging weeds and reduce evaporation of water from the soil, thus improving the chances of survival of crops in dry years. Also, the bean plants help in nitrogen fixation, improving soil fertility for the coming year (Hart, 2008).

Today, this method is generally recommended as an alternative system for small-scale farmers to improve their yield and, thus, food production and income in limited spaces. The microclimate produced by the "three sisters" combination favours the survival of the plants. Maize is notorious for extracting the $\mathrm{N}$ out of the soil and beans supply replace mineral nitrogen back into the soil. Essentially, these are the effects of crop rotation without actually having to rotate crops. Nutritionally, the „three sisters” provide a wealth of healthy foodstuff. Maize provides carbohydrates and some amino acids, beans provide the rest of the required amino acids, as well as dietary fiber, vitamins $\mathrm{B} 2$ and $\mathrm{B} 6$, potassium, zinc, manganese, iodine, iron and phosphorus, while squash provides Vitamin A. In Fig. 2 are some possible spatial arrangement of plants.
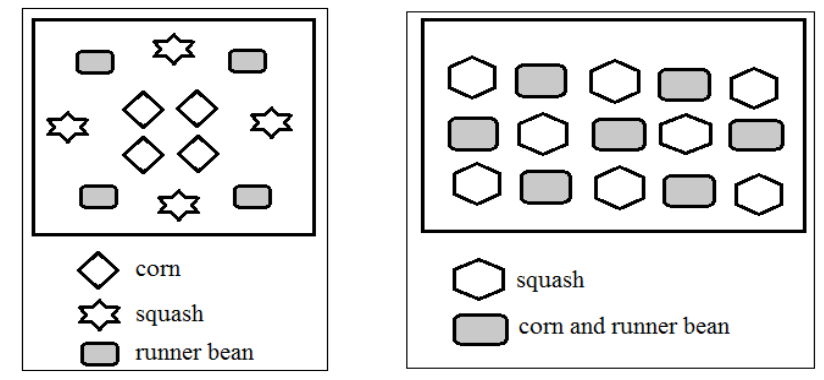

Fig. 2. "The Three Sisters Method" - row arrangements.

\section{CONCLUSIONS}

Research results around the world have shown that intercropping system has remarkable advantages, which require its reconsideration, especially in circumstances determined by the cultivated crops, ecological conditions, cultural system (conventional, unconventional), some social and economic considerations etc.

An ideal intercropping should aim to produce higher yields per area unit through better use of natural resources, offer greater stability in production under adverse weather conditions and with disease and insect infestation, provide an equitable distribution of farm resources and meet the domestic needs of the farmer.

Runner bean crop significantly capitalizes the advantages of intercropping system, for example with maize and sunflower, ensuring a support system and a favourable microclimate for plant growth and providing an intake of supplementary nitrogen for the partener plants.

Plant productivity in intercropping system using runner bean is much higher then a single crop, through a proper combination of plants or setting scheme, species with which runner bean is associated, setting era/epoch etc. Therefore, it is obviously that runner bean is a species that successfully can suit the intercropping system, in the ecological conditions of Romania.

Acknowledgments. This paper was published under the frame of European Social Fund, Human Resources Development Operational Programme 2007-2013, projectno. POSDRU/159/1.5/S/132765.

\section{REFERENCES}

1. Adetiloye PO, Ezedinma FOC and Okigho BN (1983). A land equivalent coefficient concept for the evaluation of competitive and productive interactions on simple complex crop mixtures. Ecol Modelling 19:27-39. 
2. Andrews DJ and Kassam AH (1976). The importance of multiple cropping in increasing world food supplies. R. I. Papendick, P. A. Sanchez, and G. B. Triplett (eds.). Multiple cropping Amer Soc Agron, Madison, Wis Spec Publ 27:110.

3. Anil L, Park J, Phillips RH, Miller FA (1998). Temperate intercropping of cereals for forage: A review of the potential for growth and utilization with particular refference to the UK. Grass Forage Sci 53:301-317.

4. Bowen John F, and Bernard A Kratky (1986). Successful multiple cropping requires superior management skills. Agribusiness Worldwide. November/December. p. 22-30.

5. Dakora FD (2003). Defining new roles for plant and rhizobial molecules in sole and mixed plant cultures involving symbiotic legumes. New Phytol 158:39 - 49.

6. De Wit CT (1960). On competition. Verslag Landbouwkundige Onderzock 66:1-82.

7. Eagelsham ARJ, Ayanaba A, Rao VR and Eskew DL (1982). Mineral $\mathrm{N}$ effects on cowpea and soybean crops in Nigerian soil. Plant \& Soil 68:183-192.

8. Eskandari H, Ghanbari A and Javanmard A (2009). Intercropping of cereals and legumes for forage production. Notulae Scientia Biologicae 1:07-13.

9. Hamburdă Silvia Brîndușa, Dascălu T, Munteanu N (2013). Preliminary studies for new cultivation systems of runner bean (Phaseolus coccineus L.). Lucrări științifice, seria Horticultură, USAMV Iași 56(2):167-172.

10. Hamburdă Silvia Brîndușa, Munteanu N, Popa Lorena Diana (2014). Evaluation of a runner bean (Phaseolus coccineus L.) assortment in the conditions of Iaşi county. Ştiința Agricolă. Universitatea Agrară de Stat din Moldova, Chișinău 1:38-41.

11. Hart JP (2008). Evolving the three sisters: The changing histories of maize, bean, and squash in New York and the greater Northeast. Current Northeast Paleoethnobotany II, New York State Museum Bulletin 512:87-99.

12. Haynes RJ (1980). Competitive aspects of the grasslegume association. Adv Agron 33:227-261.

13. Hiebsch CK and McCollumn RE (1987). Area x time equivalency ratio: a method of evaluating the productivity of intercrops. Agron J 79:15-22.

14. Horwith B (1985). A role for intercropping in modern agriculture. Biological Sciences 35(5): 286-291.

15. Kang BT, Grimme T and Lawson TL (1985). Alley cropping sequentially cropped maize and cowpea with leucaena on a sandy soil in Southern Nigeria. Plant and Soil 85:267277.

16. Kass DCL (1978). Polyculture cropping systems: A rewiew and analysis. Cornell Univ, Ithaca, NY Cornell Intl Agr Bul 32.

17. Lithourgidis AS, Dordas CA, Damalas CA, Vlachostergios DN (2011). Annual intercrops: an alternative pathway for sustainable agriculture. AJCS 5(4):396-410.

18. Machado Stephen (2009). Does intercropping have a role in modern agriculture? Journal of Soil and Water Conservation 64(2):55 A-57A.

19. Mazaheri D, Madani A and Oveysi M (2006). Assessing the land equivalent ratio (LER) of two corn (Zea mays L.) varieties intercropping at various nitrogen levels in Karaj, Iran. Journal of Central European Agriculture 7(2):359364.

20. Mc Gilchrist CA (1965). Analysis of competition experiments. Biometrics 21: 975-985.

21. Mousavi SR, Eskandari H (2011). A general overview on intercropping and its advantages in sustainable agriculture. J Appl Environ Biol Sci 1(11):482-486.

22. Munteanu N (1985). Phaseolus coccineus L. - a vegetable species that deserves more attention. Producția Vegetală, Horticultura 4:17-19.

23. Munteanu N (2005). Preliminary studies regarding runner bean (Phaseolus coccineus L.) species biodiversity. Lucrări ştiințifice, U.Ş.A.M.V. Iași, seria Horticultură 48(1):83-92.

24. Munteanu N, Hamburdă Silvia Brîndușa, Popa Lorena Diana (2013). Research on the main productivity features in an assortment of runner bean (Phaseolus coccineus L.) in the environmental conditions from NE Romania. Lucrări științifice, seria Agronomie, editura Ion Ionescu de la Brad, Iași 56(1):159-162.

25. Ofori F and Stern WR (1987). Cereal-legume intercropping system. Advance in Agronomy 41: 41-90.

26. Olaru C (1982). Bean. Biology and technology of the culture. Editura Scrisul românesc. Craiova, 268 p.

27. Popa Lorena Diana (2010). Research regarding Phaseolus coccineus L. species agrobiology in order to optimize cultivation. Teză de doctorat. USAMV Iaşi. 232 p.

28. Scarry CM (2008). Crop Husbandry Practices in North America's Eastern Woodlands. In: Reitz EJ, Scudder SJ, and Scarry CM, editors. Case Studies in Environmental Archaeology: Springer New York. p 391-404.

29. Stan N, Munteanu N, Stan T (2003). Vegetable growing, vol III. Editura Ion Ionescu de la Brad, Iaşi, 315p.

30. Ștefan M, Munteanu N, Stoleru V, Mihasan M (2013a). Effects of inoculation with plant growth promoting rhizobacteria on photosynthesis, antioxidant status and yield of runner bean. Rom Biotechnol Lett, 18(2):81328143.

31. Ștefan M, Munteanu N, Stoleru V, Mihasan M, Hritcu L (2013b). Seed inoculation with plant growth promoting rhizobacteria enhances photosynthesis and yield of runner bean (Phaseolus coccineus L.). Scientia horticulturae 151:22-29.

32. Trenbath BR (1976). Plant interactions in mixed crop communities. RI Papendick, PA Sanchez, and GB Triplett (eds.). Multiple cropping. ASA, CSSA, and SSSA, Madison, Wis ASA Spec Publ 27:129-170.

33. Vandermeer JH (1989). The ecology of intercropping. Cambridge University Press, Cambridge, UK.

34. Willey RW (1979a). Intercropping-Its importance and research needs. Part 1 . Competition and yield advantages. Field Crop Abstr 32:1-10.

35. Willey RW (1979b). Intercropping-Its importance and research needs. Part 2. Agronomy and research approaches. Field Crop Abstr 32:73-85. 